\title{
UJI AKTIVITAS ANTIBAKTERI DAN ANTI-UV Phyllidiella nigra DAN BAKTERI SIMBIOTIKNYA DARI PERAIRAN TANJUNG MANDOLANG
}

\author{
(ANTIBACTERIAL AND ANTI-UV ASSAYS OF Phyllidiellanigra AND ITS SYMBIOTIC \\ BACTERIA from MANDOLANG PENINSULA)
}

\author{
Tessalonica Dajoh ${ }^{1 *}$, Robert A. Bara ${ }^{1}$, Esther Angkouw ${ }^{1}$, Medy Ompi ${ }^{1}$, \\ Rosita A. J. Lintang ${ }^{1}$, Cyska Lumenta ${ }^{2}$ \\ 1) Program Studi IImu Kelautan, FPIK, UNSRAT \\ 2) Program Studi Budidaya Perairan, FPIK, UNSRAT \\ ${ }^{\star} \mathrm{E}$ - mail : tessalonicadajoh@gmail.com
}

\begin{abstract}
Phyllidiella nigra is an organism that is suspected to have secondary metabolites because their ability to develop its self defense system by camouflage and using chemical compounds derived from their nature diet as deterrent against their predators. The purpose of this study was to isolate symbiotic bacterial derived from $P$. nigra, extracted and followed by, the antibacterial assays against Escherichia coli and Bacillus megaterium as well as the anti-UV assay. The results showed that the five isolates tested had an antibacterial activity with the highest average inhibition zone against $E$. coli DSM 498 bacteria, isolate $1(14.67 \mathrm{~mm})$, isolate $5(14 \mathrm{~mm})$, and against $B$. Megaterium DSM $32^{\top}$ bacteria, isolate 3 $(13.33 \mathrm{~mm})$. The three isolates which had the highest inhibition zone and $P$. nigra extract were tested for anti-UV assay using a UV-Vis Spectrophotometer. The results obtained isolate 3 has absorption of UV-A with the UV absorbtion maximum at $\lambda 340 \mathrm{~nm}$ and $P$. nigra extract has absorption on UV-B radiation with UV absorption maximum at $\lambda 290 \mathrm{~nm}$.

Key words: Nudibranchia, Bacteria, Anti-bacteial, Anti-UV

Phyllidiella nigra merupakan organisme yang diduga memiliki metabolit sekunder karena mampu mengembangkan sistem pertahanan dirinya dengan cara kamuflase dan menggunakan senyawa kimia sebagai racun yang didapat dari makanannya. Tujuan dari penelitian ini yaitu mendapatkan isolat bakteri yang bersimbiosis dengan $P$. nigra, mendapatkan ekstrak dari baktri simbion, dan menguji antibakteri dan anti-UV ekstrak etil aseta bakteri simbion dengan metode difusi agar terhadap bakteri Escherichia coli dan Bacillus megaterium. Hasil penelitian didapatkan kelima isolat yang diuji memiliki aktivitas antibakteri dengan rerata zona hambat tertinggi terhadap bakteri $E$. coli DSM 498 yaitu isolat $1(14,67 \mathrm{~mm})$, isolat 5 $(14 \mathrm{~mm})$, dan terhadap baktri $B$. megaterium DSM $32^{\top}$ yaitu isolat $3(13,33 \mathrm{~mm})$. Ketiga isolat yang memiliki zona hambat tertinggi dan ekstrak $P$. nigra diujikan anti-UV menggunakan alat UV-Vis Spektrofotometer. Hasil yang didapat isolat 3 memiliki serapan terhadap radiasi sinar UV-A dengan puncak tertinggi pada $\lambda 340 \mathrm{~nm}$ dan ekstrak $P$. nigra memiliki serapan terhadap radiasi sinar UV-B dengan puncak tertinggi berada pada $\lambda 290 \mathrm{~nm}$.
\end{abstract}

Kata kunci: Nudibranchia, Bacteria, Anti-bacteial, Anti-UV 


\section{PENDAHULUAN}

Indonesia memiliki keanekaragaman hayati tinggi yang bukan hanya sebagai sumber makanan, sumber daya laut juga dapat dikembangkan sebagai bahan obat seperti, antikanker, anti jamur, antibakteri dan anti-UV. Beberapa biota laut yang menghasilkan bahan hayati yang memiliki aktivitas biologis diantaranya yaitu spons, ascidian, bryozoa, dan moluska (Proksch $d k k, 2002)$. Menurut Pringgenies (2015), invertebrata laut merupakan organisme laut yang menghasilkan senyawa bioaktif terbesar yang berpotensi sebagai bahan obat. Senyawa bioaktif yang dihasilkan ini merupakan respon invertebrata laut terhadap pergerakan fisiknya yang lebih terbatas dibanding vertebrata laut.

Salah satu invertebrata laut yang diteliti memiliki senyawa bioaktif adalah nudibranchia. Organisme ini diduga menghasilkan metabolit sekunder karena mampu mengembangkan sistem pertahanan dirinya dengan cara kamuflase dan menggunakan senyawa kimia sebagai racun yang didapat dari makanannya (Pringgenies, 2015). Salah satu senyawa bioaktif yang diduga dihasilkan nudibranchia yaitu antibakteri (Fisch et al., 2017; Bohringer et al., 2017). Antibakteri atau antimikroba merupakan senyawa bioaktif yang digunakan untuk mengobati infeksi yang disebabkan oleh bakteri. Nudibranchia Jorunna funebris dalam penelitian yang pernah ada, diketahui menghasilkan senyawa isoquinoline alkaloid (Jorumycin) yang potensial sebagai antimikroba dan antitumor (Yan, 2004). Penelitian terbaru nudibranchia Doriprismatica stellata (Chromodorididae, Doridoidea) menghasilkan senyawa baru golongan sesterterpen yang memiliki aktivitas terhadap bakteri Gram positif (Hertzer et al., 2020).

Senyawa bioaktif yang diketahui dihasilkan dari nudibranchia menjadikan semakin banyak peneliti yang mengambil organisme ini untuk diteliti, sementara ketersediaan biota ini di alam sangat terbatas. Penelitian ini dilakukan dengan mengambil dan memanfaatkan bakteri yang bersimbiosis dengan Phyllidiella nigra yang dapat menghasilkan senyawa metabolit sekunder yang sama dengan inangnya (Pringgenies, 2009).

Contoh bakteri yang dapat menyebabkan infeksi yaitu, Escherichia coli. Bakteri ini merupakan bakteri patogen yang menyebabkan infeksi pada saluran kemih yang terjadi ketika saluran terhambat atau disebabkan oleh UPEC (Uropathogenic E. coli) (Runtuwene $d k k, 2017)$. Ping Guo dkk (2015) menjelaskan dari Duncan and Smith (2011) bahwa adanya infeksi kulit yang disebabkan oleh bakteri Bacillus megaterium.

Perubahan iklim yang signifikan diakibatkan oleh pemanasan global mengakibatkan terjadinya penipisan lapisan ozon yang berfungsi sebagai penyaring cahaya matahari yang masuk ke bumi. Lapisan ozon bila semakin menipis mengakibatkan cahaya matahari dapat menyebabkan berbagai penyakit kulit pada manusia, sebagai contoh yaitu peradangan kulit atau dermatitis. Senyawa anti-UV juga sebagai bahan pembuatan sunscreen/sunblock memiliki kemampuan untuk menyerap sinar matahari (Soeratri dan Purwanti, 2004).

Tujuan dari penelitian ini yaitu mendapatkan isolat bakteri yang bersimbiosis dengan $P$. nigra, mendapatkan ekstrak dari bakteri simbion, dan menguji antibakteri dan anti-UV ekstrak etil asetat bakteri simbion dengan metode difusi agar terhadap bakteri Escherichia coli dan Bacillus megaterium. 


\section{METODE PENELITIAN}

\section{Pembuatan Media Marine Broth}

Media Marine Broth adalah media yang digunakan untuk menumbuhkan bakteri pertama kali dan media yang dibawah pada saat sampling. Media dibuat dengan melarutkan media sebanyak 3,8 gram dalam erlenmeyer berisi $100 \mathrm{ml}$ akuades, selanjutnya disterilkan menggunakan otoklaf pada suhu $121^{\circ} \mathrm{C}$ selama \pm 20 menit.Setelah disterilisasi, media dipindahkan ke eppendorf steril yang telah disiapkan.

\section{Pengambilan Sampel}

Pada penelitian ini sampel diperoleh dari Perairan Tanjung Mandolang (Gambar 1) dengan cara menyelam menggunakan alat SCUBA pada kedalaman sekitar 15 meter. Pengambilan sampel dilakukan dengan cara mengambil sampel langsung dari substratnya kemudian dimasukkan ke dalam botol sampel untuk selanjutnya dibawa ke darat.

\section{Identifikasi dan Penanganan Sampel}

Identifikasi sampel dilakukan dengan cara mengamati sampel menurut pola, warna, dan bentuk tubuh dipandu menggunakan buku "Nudibranch \& Sea Slug Identification"(Gosliner dkk, 2018).

Sampel dicelupkan ke etanol selama \pm 3 detik kemudian potong bagian tengah tubuh sampel sekitar $1 \mathrm{~cm}$ dan masukkan ke media Marine Broth. Bagian tubuh sampel yang masih tersisa rendam dengan etanol 96\%. Inkubasi media Marine Broth yang berisi sampel selama $2 \times 24$ jam dan dibawa ke Laboratorium Biologi Molekuler dan Farmasetika Laut, Fakultas Perikanan dan IImu Kelautan, UNSRAT, untuk dilakukan penelitian lebih lanjut.

\section{Sterilisasi Alat dan Bahan}

Alat-alat yang digunakan dalam penelitian ini seperti cawan petri, tabung reaksi, erlenmeyer dan pinset dicuci bersih, dikeringkan, dibungkus kemudian disterilkan dalam oven pada suhu $150^{\circ} \mathrm{C}$ selama \pm 2 jam (sterilisasi kering). Media untuk pertumbuhan mikroorganisme disterilisasi dalam autoklaf pada suhu $121^{\circ} \mathrm{C}$ selama 15 menit (sterilisasi basah).

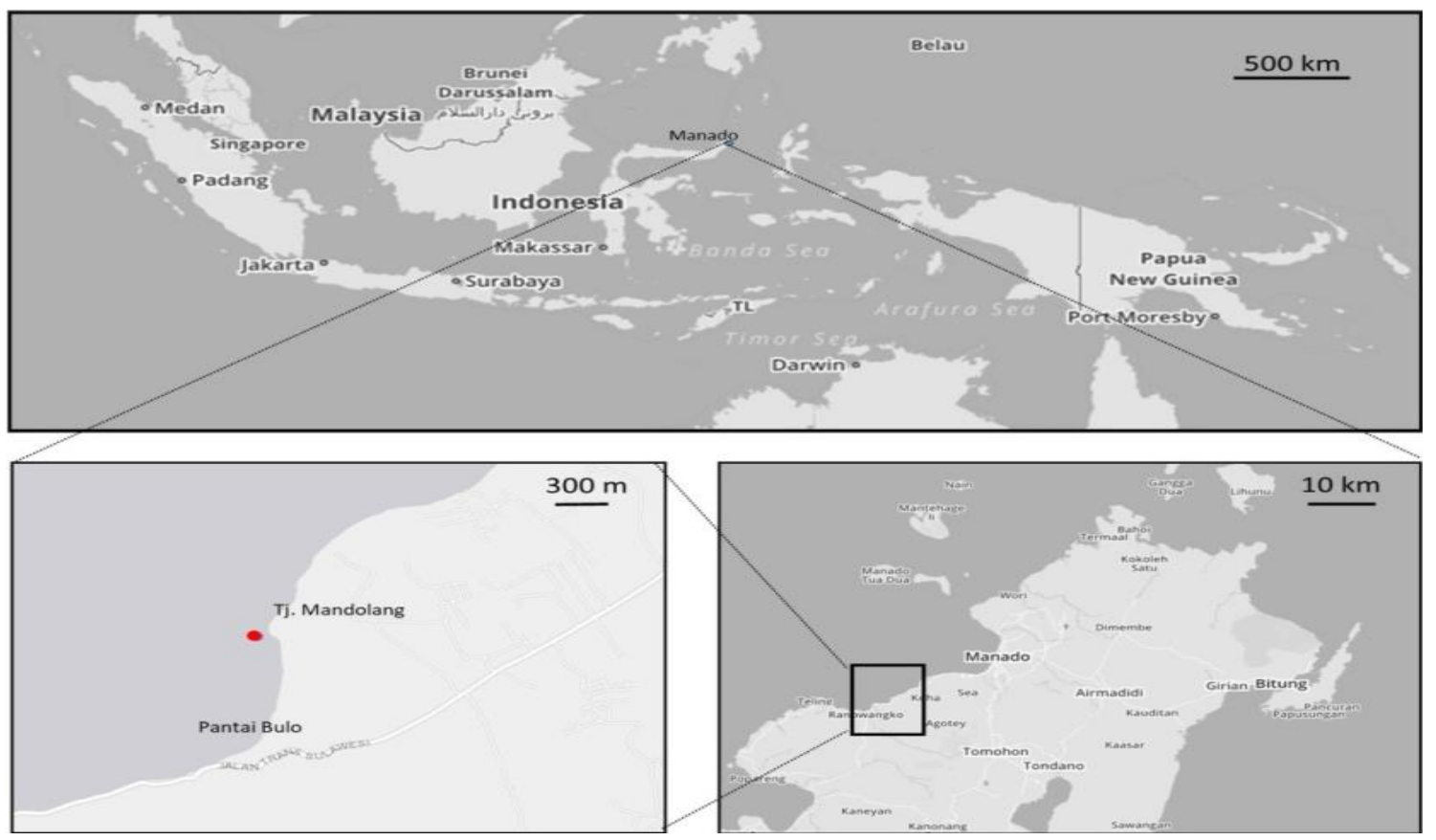

Gambar 1. Peta Lokasi Pengambilan Sampel 


\section{Pembuatan Media Nutrient Agar}

Pembuatan media Nutrient Agar dilakukan dengan melarutkan 2,8 gram NA dalam erlenmeyer berisi $100 \mathrm{ml}$ air laut saring $50 \%$. Sterilkan media menggunakan otoklaf pada suhu $121^{\circ} \mathrm{C}$ selama \pm 20 menit.

\section{Isolasi Bakteri Simbion Phyllidiella nigra \\ Ambil media Marine Broth berisi} sampel sebayak $100 \mu \mathrm{l}$ menggunakan mikropipetkemudian disebar pada media Nutrient agar. Jarum ose yang telah steril digoreskan pada media yang telah disebar membentuk pola zigzag. Selanjutnya media diinkubasi selama 1 × 24 jam.

\section{Pembuatan Media NA (Nutrient Agar)}

Media NA ditimbang sebanyak 5,6 gram dan dilarutkan dalam $200 \mathrm{ml}$ akuades. Selanjutnya media disterilisasi basah mengunakan otoklaf pada suhu $121^{\circ} \mathrm{C}$ selama \pm 20 menit.

\section{Pemurnian Bakteri}

Pemurnian bakteri merupakan proses yang dilakukan untuk mendapatkan koloni terpisah yang merupakan biakan murni. Pemurnian bakteri dilakukan dengan cara mengambil koloni tunggal bakteri menggunakan jarum ose steril, selanjutnya goreskan koloni tunggal pada media NA membentuk pola zigzag. Media diinkubasi selama 1 × 24 jam. Pemurnian bakteri dilakukan berulang-ulang hingga mendapatkan koloni terpisah.

\section{Pembuatan Media BHI (Brain Heart Infusion)}

Pembuatan media BHI dilakukan dengan menimbang media Brain Heart Infusion 3,7 gr kemudian dilarutkan dengan $100 \mathrm{ml}$ akuades, komposisi tersebut dibuat untuk setiap erlenmeyer dan menggunakan 5 erlenmeyer untuk 5 bakteri biakan murni. Media disterilisasi basah mengunakan otoklaf pada suhu $121^{\circ} \mathrm{C}$ selama \pm 20 menit.

\section{Ekstraksi Bakteri Simbion Phyllidiella nigra}

Proses ekstraksi pertama dilakukan dengan cara mengkultur bakteri simbion dalam media $\mathrm{BHI}$ dengan tujuan untuk memperoleh bakteri dalam jumlah yang banyak. Bakteri biakan murni diambil menggunakan jarum ose dan pindahkan ke dalam media $\mathrm{BHI}$, selanjutnya inkubasi selama $2 \times 24$ jam menggunakan alat shaker.

Ekstraksi adalah proses yang digunakan untuk memisahkan suatu bahan dari campurannya degan menggunakan pelarut yang sesuai (Mukhriani, 2014). Bakteri yang telah dikultur pada media $\mathrm{BHI}$ dimaserasi dengan cara menambahkan pelarut etil asetat sebanyak $100 \mathrm{ml}$, selanjutnya inkubasi selama $2 \times 24$ jam.

Media BHI yang telah dimaserasi dilakukan partisi menggunakan labu pisah. Fraksi etil asetatyan dioperoleh kemudian dievaporasi menggunakan rotary vacuum evaporator pada suhu $40^{\circ} \mathrm{C}$ hingga mendapatkan ekstrak etil asetat.

\section{Pembuatan Kontrol}

Dalam pengujian antibakteri, untuk melihat ada atau tidaknya zona hambat dan aktivitas antibakteri dari sampel diperlukan kontrol positif yang akan digunakan sebagai tolok ukur. Pembuatan kontrol positif menggunakan $250 \mathrm{mg}$ kloramfenikol yang dilarutkan dalam $250 \mathrm{ml}$ akuades. Sedangkan untuk kontrol negatif menggunakan etanol dengan kosentrasi $40 \%$.

\section{Pembuatan Media Nutrient Broth}

Pembuatan media Nutrient Broth dilakukan dengan cara menimbang media 0,65 gram dan dilarutkan dalam $50 \mathrm{ml}$ akuades. Media kemudian dipindahkan ke tabung-tabung reaksi sebanyak $5 \mathrm{ml}$, selanjutnya otoklaf media pada suhu $121^{\circ} \mathrm{C}$ selama \pm 20 menit.

\section{Peremajaan Bakteri Uji}

Bakteri yang digunakan pada saat

pengujian antibakteri yaitu bakteri

Escherichia coli DSM 498 dan Bacillus 
megaterium DSM 32'. Kedua bakteri uji diperoleh dari Deutsche Sammlung von Mikroorganismen und Zellkulturen (DSMZ), Braunschweig, Jerman. Peremajan bakteri dilakukan dengan cara bakteri uji yang telah disiapkan diambil menggunakan jarum ose steril dan dipindahkan ke tabung reaksi berisi media Nutrient Broth, selanjutnya inkubasi selama $1 \times 24$ jam.

\section{Pembuatan Media NA (Nutrient Agar)}

Pembuatan

media

NA

menggunakan 2 erlenmeyer untuk 2 bakteri uji yang berbeda. Media NA ditimbang sebanyak 1,4 gam dan dilarutkan dalam 50 $\mathrm{ml}$ akuades, komposisi ini digunakan untuk setiap erlenmeyer. Media selanjutnya disterilisasi basah mengunakan otoklaf pada suhu $121^{\circ} \mathrm{C}$ selama \pm 20 menit, kemudian dinginkan media pada suhu ruangan selama \pm 15 menit.Bakteri uji ditambahkan ke dalam media NA sebanyak $1500 \mu \mathrm{l}$ menggunakan mikropipet, selanjutnya tuang media pada cawan petri steril.

\section{Pengujian Antibakteri}

Pengujian antibakteri dilakukan dengan cara kertas cakram steril ditempelkan pada media NA, kemudian ekstrak etil asetat yang didapat dan ekstrak $P$. nigra diambil sebanyak $20 \mu \mathrm{l}$ dan ditotolkan di atas kertas cakram. Pengujian antibakteri dilakukan sebanyak 3 kali ulangan, kemudian inkubasi selama 1×24 jam untuk melakukan pengamatan. Adanya zona hambat (inhibitory zone/clear zone) merupakan tanda adanya kepekaan terhadap bakteri uji.

\section{Pengujian Anti - UV}

Pengujian anti UV menggunakan alat UV-Visible Spectrophotometer. Ekstrak etil asetat bakteri dan ekstrak $P$. nigra diuji pada panjang glombang 280-360 nm. Untuk melihat apakah sampel memiliki anti-UV adalah dengan melihat nilai absorbansi yang ditunjukkan alat spektrofotometer pada saat panjang gelombang berada di $\lambda$ 290-360 nm.

\section{HASIL DAN PEMBAHASAN}

\section{Pengambilan Sampel}

Pengambilan sampel dilakukan pada siang hari sekitar pukul 11.00 - 13.00 WITA dengan kondisi perairan Tanjung Mandolang sedang surut dan cuaca cerah pada saat itu sehingga membantu pengambilan sampel.

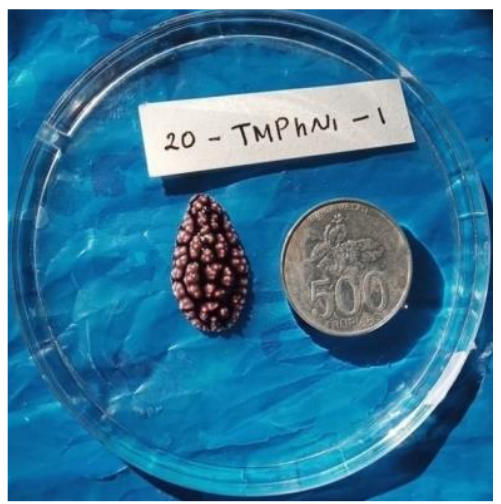

Gambar 2. Sampel Phyllidiella nigra

\section{Identifikasi dan Penanganan Sampel} Sampel Phyllidiella nigra (Gambar 2) diperoleh saat sampling kemudian diidentifikasi dengan mengamati morfologinya dibantu dengan buku "Nudibranch \& Sea Slug Identification" (Gosliner dkk., 2018). Diketahui bahwa sampel yang diperoleh benar-benar organisme Phyllidiella nigra karena memiliki bentuk tubuh oval dan cembung dengan tubuh berwarna hitam dan tuberkel merah muda.

Sampel dipotong bagian tengah tubuhnya sekitar $1 \mathrm{~cm}$ dan dimasukkan ke dalam media Marine Broth untuk isolasi bakteri simbion (Gambar 3). Bagian tubuh sampel yang masih tersisa diekstrak dengan etanol 96\% (Gambar 4). 


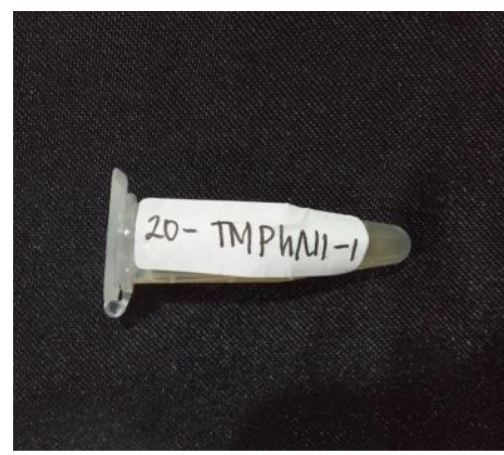

Gambar 3. Isolasi sampel dalam media Marine Broth

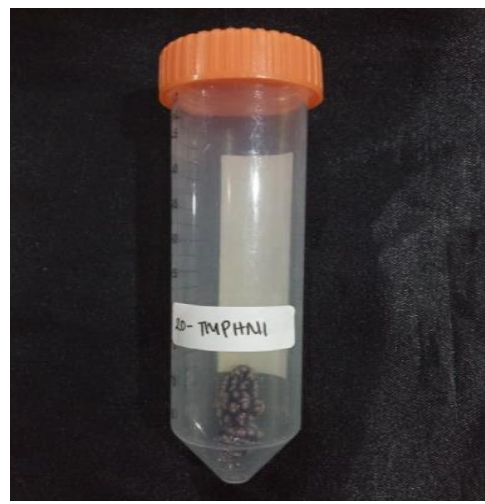

Gambar 4. Sampel dalam rendaman etanol

\section{Isolasi Bakteri Phyllidiella nigra}

Bakteri yang telah diinkubasi selama $2 \times 24$ jam dan telah tumbuh pada media Marine Broth kemudian diisolasi pada media Nutrient Agar. Hasil isolasi bakteri setelah diinkubasi $1 \times 24$ jam terlihat bakteri tumbuh dengan beberapa koloni tunggal yang berbeda (Gambar 5).

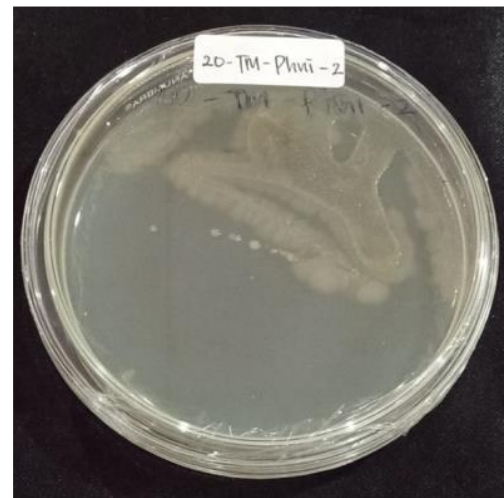

Gambar 5. Hasil isolasi bakteri
Bakteri hasil isolasi diambil 5 koloni tunggal dan dilakukan pemurnian. Koloni tunggal yang diambil adalah yang berbentuk titik-titik kecil terpisah dari koloni bakteri yang besar dan memiliki karakterisasi yang berbeda dari bakteri yang lain.

\section{Pemurnian Bakteri}

Koloni tunggal yang diperoleh kemudian dipisahkan dan ditumbuhkan kembali pada media yang baru dan diamati pertumbuhannya. Koloni bakteri yang sudah murni ditandai dengan isolat murni bakteri yang telah memiliki kesamaanbentuk dan warna.Pada tabel dibawah (Tabel 1) menunjukkan kenampakan dan karakterisasi dari isolat yang sudah murni.

Tabel 1. Hasil isolat murni bakteri simbion Phyllidiella nigra

\begin{tabular}{|l|c|}
\hline \multicolumn{1}{|c|}{ Kode } & $\begin{array}{c}\text { Isolat murni bakteri simbion } P . \\
\text { nigra }\end{array}$ \\
\hline 20-Phni- & 20-Tm-PhN $1-1-1$ \\
\hline $20-$ Phni-1- & \\
\hline
\end{tabular}




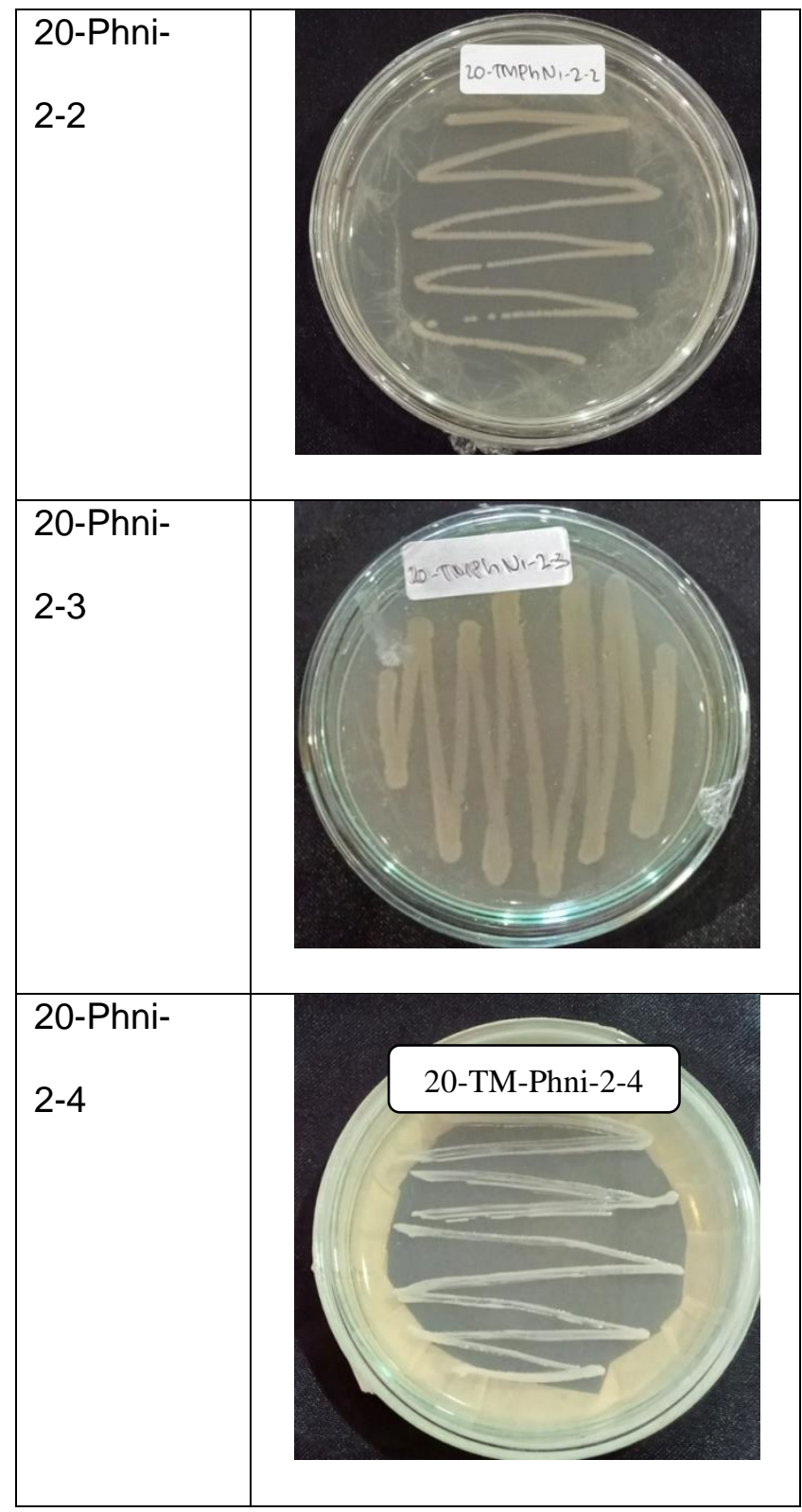

Ekstraksi Bakteri Simbion Phyllidiella nigra

Isolat bakteri yang telah dimurnikan dikultur pada media cair BHI (Gambar 6), selanjutnya dimaserasi menggunakan etil asetat selama $2 \times 24$ jam (Gambar 7).

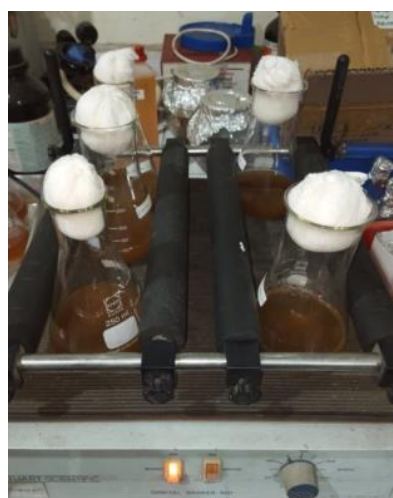

Gambar 6. Kultur bakteri dalam media BHI

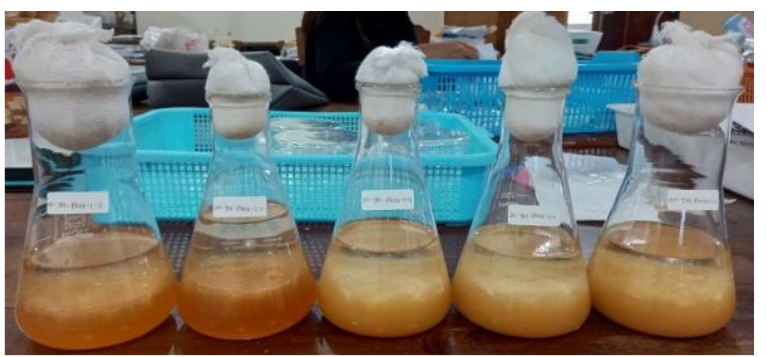

Gambar 7. Proses maserasi isolat bakteri

Setelah proses maserasi, media Brain Heart Infusion dan etil asetat kemudian dimasukkan ke dalam labu pisah dan dicampur hingga homogen untuk dilakukan partisi.

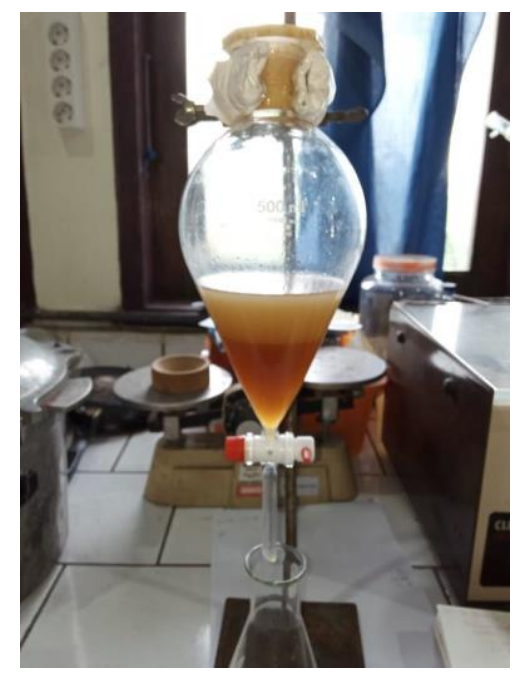

Gambar 8. Proses partisi 

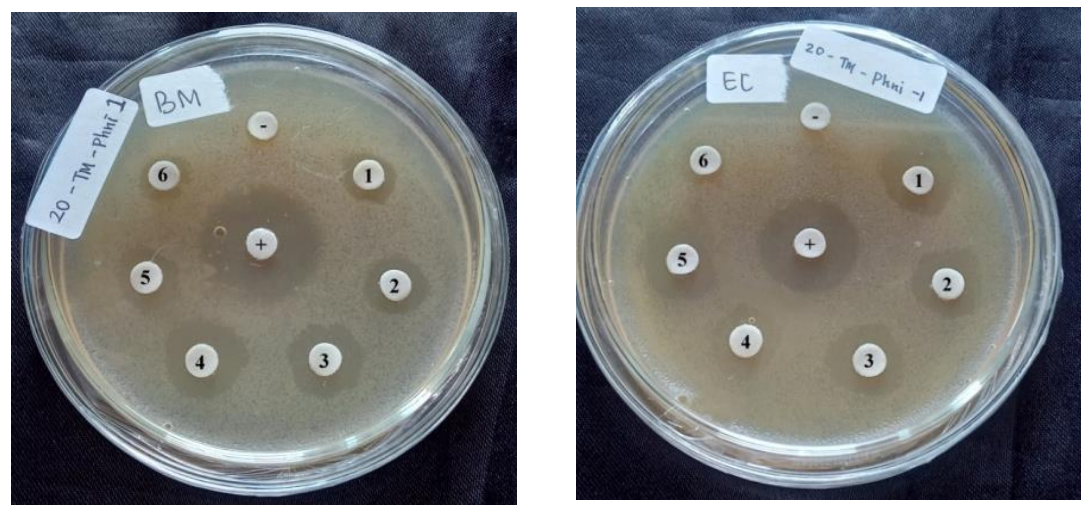

Gambar 9. Hasil uji aktivitas antibakteri

Fraksi etil asetat yang diperoleh kemudian dievaporasi menggunakan rotary vacuum evaporator pada suhu $40^{\circ} \mathrm{C}$ hingga mendapatkan ekstrak.

\section{Pengujian Antibakteri}

Aktivitas anti bakteri dilihat dengan adanya zona hambat pada sekitar kertas cakram.Hasil pengamatan aktivitas antibakteri pada media bakteri E. coliDSM 498 dan bakteri $B$. megaterium DSM $32^{\top}$ pada ketiga ulangan (Tabel 3 ) hampir semua memiliki zona hambat (inhibitory zone). Hanya ekstrak etil asetat isolat $4 /$ Phni 2-3, ekstrak etil asetat isolat 5 / Phni 24, ekstrak etil asetat isolat 6 / Sampel Phni pada ulangan kedua media bakteri

B.megaterium DSM $32^{\top}$ dan ekstrak etil asetat isolat 4 / Phni 2-3 pada ulangan ketiga media bakteri $E$. coli DSM 498 tidak memiliki zona hambat (inhibitory zone).

Penggolongan kriteria kekuatan suatu bahan antibakteri, yakni diameter zona hambat $5 \mathrm{~mm}$ atau kurang dikategorikan lemah, zona hambat 5-10 mm dikategorikan sedang, sedangkan diameter zona hambat $10-20 \mathrm{~mm}$ dikategorikan kuat dan diameter zona hambat yang melebihi dari $20 \mathrm{~mm}$ dikategorikan sangat kuat (Davis dan Stout, 1971).

Pada penelitian yang dilakukan tampak bahwa kontrol positif kloramfenikol (Gambar 9) jauh lebih efisien untuk menghambat pertumbuhan bakteri uji

Tabel 2. Hasil uji aktivitas antibakteri

\begin{tabular}{|c|c|c|c|c|c|c|c|c|}
\hline \multirow{3}{*}{$\begin{array}{l}\text { Kode / Isolat } \\
\text { Phni 1-1 }\end{array}$} & \multicolumn{8}{|c|}{ Bakteri Uji } \\
\hline & \multicolumn{3}{|c|}{ E. coliDSM $498(\mathrm{~mm})$} & \multirow{2}{*}{$\begin{array}{l}\text { Rerata } \\
14,67 \pm 2,3\end{array}$} & \multicolumn{3}{|c|}{$\begin{array}{l}\text { B. megaterium } \\
\text { DSM32 }^{\top}(\mathrm{mm})\end{array}$} & \multirow{2}{*}{$\begin{array}{c}\text { Rerata } \\
11,33 \pm 4,5\end{array}$} \\
\hline & 16 & 12 & 16 & & 11 & 16 & 7 & \\
\hline Phni 1-2-2 & 14 & 13 & 12 & $13,00 \pm 1,0$ & 13 & 12 & 8 & $11 \pm 2,6$ \\
\hline Phni 2-2 & 14 & 12 & 11 & $12,33 \pm 1,5$ & 14 & 13 & 13 & $13,33 \pm 0,6$ \\
\hline Phni 2-3 & 15 & 11 & - & $8,67 \pm 2,8$ & 14 & - & 7 & $10,5 \pm 4,9$ \\
\hline Phni 2-4 & 15 & 13 & 14 & $14,00 \pm 1,0$ & 12 & - & 12 & $12,00 \pm 0,0$ \\
\hline Sampel Phni & 9 & 10 & 9 & $9,33 \pm 0,6$ & 10 & - & 8 & $9,00 \pm 1,4$ \\
\hline Kontrol Positif & 20 & 22 & 19 & $20,33 \pm 1,5$ & 23 & 20 & 16 & $19,67 \pm 3,5$ \\
\hline $\begin{array}{l}\text { Kontrol } \\
\text { Negatif }\end{array}$ & - & - & - & - & - & - & - & - \\
\hline
\end{tabular}


Dengan rerata zona hambatnya pada bakteri E. coli DSM 498 sebesar (20,33 $\mathrm{mm}$ ) dan pada bakteri B. megaterium DSM $32^{\top}$ menghasilkan rerata zona hambat sebesar $(19,67 \mathrm{~mm})$. Faktor yang mempengaruhi hal di atas karena Minimum Inhibitory Concentration (MIC) kloramfenikol telah diketahui kosentrasi yang paling tepat untuk menghambat aktivitas pertumbuhan bakteri (Opa dkk., 2018). Kloramfenikol telah diketahui merupakan antibiotik berspektrum luas. Senyawa antibakteri dapat digolongkan juga sebagaispektrum luas dan spektrum sempit. Spektrum luas yang senyawa tersebut bekerja aktif terhadap banyak jenis bakteri, baik bakteri Gram positif maupun bakteri Gram negatif. Sedangkan spektrum sempit artinya suatu senyawa yang bekerja hanya terhadap satu golongan bakteri saja, baik pada bakteri Gram positif atau hanya pada bakteri Gram negatif (WHO, 2014). Dari hasil penelitian menunjukkan bahwa senyawa antibakteri yang terdapat pada ekstrak etil asetat bakteri simbion Phyllidiella nigra termasuk berspektrum luas dikarenakan memiliki kemampuan menghambat bakteri Gram positif dan bakteri Gram negatif.

$$
\text { Phyllidiella nigra }
$$

diduga

menghasilkan metabolit sekunder sebagai pertahanan diri terhadap lingkungannya. Organisme laut, khususnya yang hidup di daerah tropis untuk kelangsungan hidupnya menghadapi berbagai tantangan, harus berkompetisi untuk mendapatkan ruang tumbuh, sinar dan makanan. Metabolit sekunder yang dihasilkan mungkin saja bisa diproduksi sendiri oleh organisme dan bisa diproduksi dari sumber makanan. Sebagian besar invertebrata laut yang dapat bergerak menggunakan senyawa kimia dari biota yang dimakannya untuk dimanfaatkan sebagai senjata melawan predator (Murniasih, 2005).

Sebagai contoh dalam Murniasih (2005) yaitu Nudibranch Hexabranchus sanguineus memakan spons jenis Halichondria yang memproduksi senyawa macrolides-oxazole halichondramide. Spesies nudibranchia lainnya, Doriprismatica stellata mengakumulasi senyawa baru golongan sesterterpen yang memiliki aktivitas terhadap bakteri Gram positif, senyawa yang sama juga diamati terdapat pada telur nudibranchia tersebut dan pada spons Spongia cf. agaricina yang merupakan diet alami nudibranchia di atas. Diduga senyawa ini berperan penting sebagai proteksi terhadap invasi bakteri (Hertzer et al., 2020). Umumnya senyawa yang dihasilkan nudibranchia dalam konsentrasi yang rendah namun dapat digunakan sebagai senjata kimia yang ampuh dalam menghadapi predasi ikan dan biota laut lainnya atau melawan infeksi mikroorganisme patogen. (Pawlik dkk., 1988). Menurut Rinehart (1992), apabila tekanan lingkungannya relatif tinggi maka senyawa yang dihasilkan akan banyak. Hasil penelitian yang menunjukkan bahwa senyawa antibakteri dari bakteri simbion Phyllidiella nigra termasuk dalam golongan kuat merupakan petunjuk bahwa tekanan di lingkungan tempat hidupnya relatif tinggi.

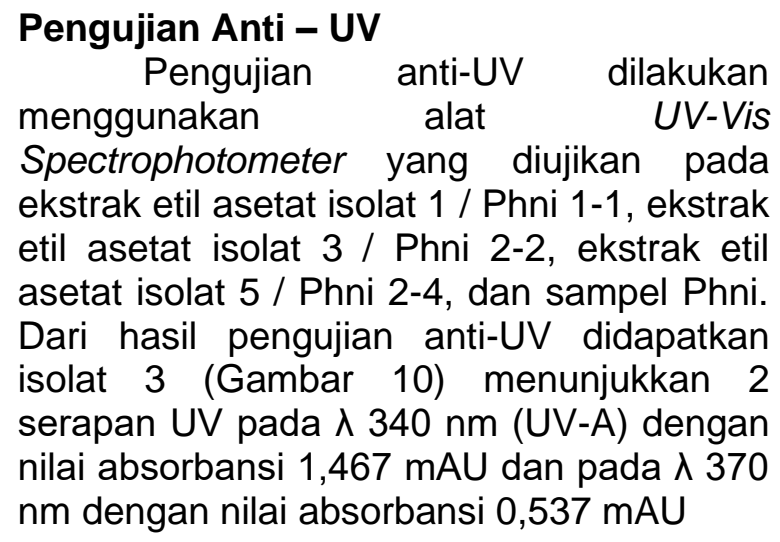




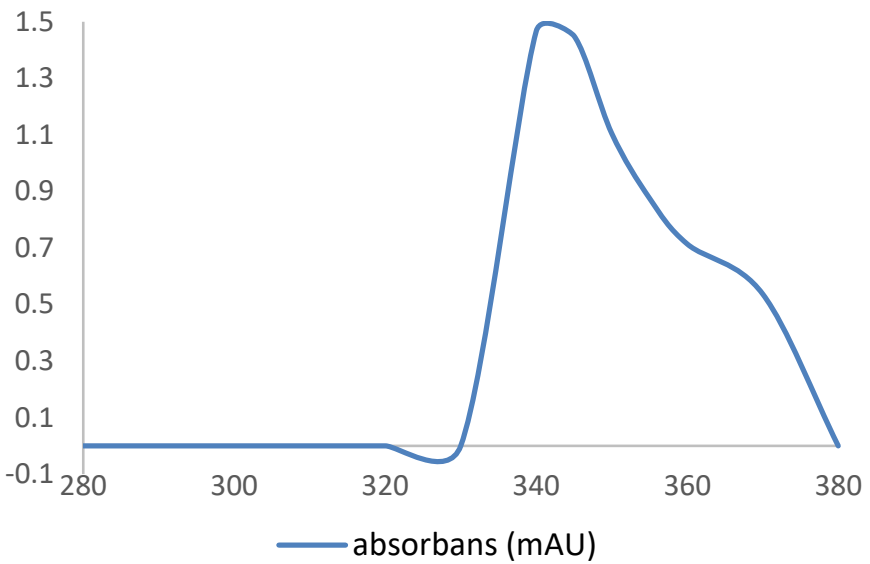

Gambar 10. Grafik hasil pengujian anti-UV ekstrak bakteri isolat 3

Pengujian anti-UV dari ekstrak Phyllidiella nigra (Gambar 11) menunjukkan adanya 3 serapan UV pada $\lambda 290 \mathrm{~nm}$ (UVB) dengan nilai absorbansi $1,126 \mathrm{mAU}$, pada $\lambda 320 \mathrm{~nm}$ dengan nilai absorbansi $0,695 \mathrm{mAU}$, dan pada $\lambda 345 \mathrm{~nm}$ dengan nilai absorbansi $0,450 \mathrm{mAU}$.

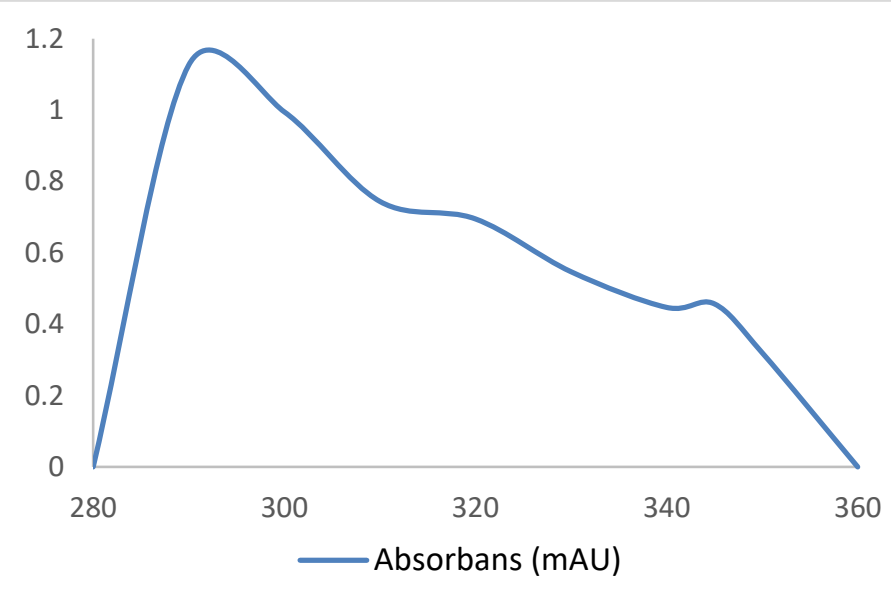

Gambar 11. Grafik hasil pengujian anti-UV sampel Phyllidiella nigra

Hasil yang didapat dari pengujian spektrofotometer menunjukkan bahwa ekstrak Phyllidiella nigra maupun bakteri dari sampel Phyllidiella nigra memiliki substansi anti-UV. Senyawa anti-UV yang dihasilkan diduga merupakan bentuk adaptasi organisme ini terhadapan paparan radiasi UV, yang kemudian senyawa ini dapat diterapkan oleh manusia sebagai bahan pembuatan tabir surya yang berpotensi melawan ataupun mengurangi pengaruh buruk dari radiasi UV. Beberapa organisme laut yang hidup pada daerah perairan dangkal maupun daerah pasang surut ditemukan memiliki senyawa organik yang bersifat sebagai anti-UV yaitu Mycosporine-like amino acids (MAAs) (Dunlap \& Shick, 1998). Mycosporine merupakan salah satu sistem pertahanan diri organisme laut dari radiasi sinar UV (Warouw dan Losung, 2015).

\section{KESIMPULAN}

Berdasarkan hasil penelitian yang dilakukan, maka dapat disimpulkan bahwa:

1. Dari pengujian antibakteri yang dilakukan menunjukkan bahwa ekstrak $P$. nigra dan bakteri simbion Phyllidiella nigra memiliki aktivitas antibakteri terhadap kedua bakteri uji dan diketahui senyawa antibakteri yang dihasilkan berspektrum luas atau senyawa yang bekerja pada bakteri gram positif dan gram negatif.

2. Pengujian anti-UV yang dilakukan menunjukkan serapan pada ekstrak etanol $P$. nigra memiliki aktivitas anti-UV-B dan ekstrak etil asetat isolat bakteri 3 memiliki aktivitas anti-UV-A yang dapat berpotensi sebagai bahan tabir surya.

\section{DAFTAR PUSTAKA}

Bohringer, N., Fisch, K. M., Schillo, D., Bara, R., Hertzer, C., Grein, F., Eisenbarth, J. H., Kaligis, $F$., Schneider, T., Wagele, H., Konig, G. M., Schaberle, T. F. 2017. Antimicrobial Potential of Bacteria Associated with Marine Sea Slugs from North Sulawesi, Indonesia. Frontiers in Microbiology Vol. 8.

Davis, W. W., T. R. Stout. 1971. Disc plate methods of microbiological antibiotic assay. Microbiology 22: 659-665. 
Dunlap, W. C. and Shick, M. J. 1988. Ultraviolet Radiation Absorbing Mycosporin Like Amino Acids in Coral Reef Organisms : A Biochemical and Environmental Perspective. J. Phycol. 34, 418-430.

Fisch, K. M., Hertzer, C., Böhringer, N., Wuisan, Z. G., Schillo, D., Bara, R., Kaligis, F., Wägele, H., König, G. M., Schäberle, T. F. 2017. The Potential of Indonesian Heterobranchs Found around Bunaken Island for the Production of Bioactive Compounds. Marine Drugs, 15, 384.

Gosliner, T. M., Valdes, A., Behrens, D. W. 2018. Nudibranch \& Sea Slug Identification - Indo-Pacific $-2^{\text {nd }}$ Edition

Hertzer, C., Kehraus, S., Bohringer, N., Kaligis, F., Bara, R., Erpenbeck, D., Worheide, G., Schaberle, T. F., Wagele, H., Konig, G. M. 2020. Antibacterial scalarane from Doriprismatica stellatanudibranchs (Gastropoda, Nudibranchia), egg ribbons, and their dietary sponge Spongia cf. agaricina(Demospongiae,

Dictyoceratida). Beilstein J. Org. Chem, 16, 1596-1605.

Murniasih, T. 2005. Substansi Kimia Untuk Pertahanan Diri Dari Hewan Laut Tak Bertulang Belakang. Oseana Vol. 30. No. 2.

Opa, S. L., Bara, R. A., Gerung G. S., Rompas, R. M. Lintang, R. A. J., Sumilat, D. A. 2018. Uji Aktivitas Antibakteri Fraksi N-Heksana, Metanol Dan Air Dari Ascidian Lissoclinum sp. Jurnal Pesisir dan Laut Tropis. Vol. 1. No. 1. Hal. 6980.

Pawlik, J. R., Kernan. M. R., Molinski. T. F., Harper. M. K., Faulkner. D. J. 1988. Defensive Chemicals of the Spanish Dancer Nudibranch Hexabranchus sanguineus and Its Egg Ribbons: Macrolides Derived From a Sponge Diet. J. Exp. Mar. Biol. Ecol., Vol. 119 (99-109).
Ping Guo, F., Wei Fan, H., Yin Liu, Z., Wei Yang, Q., Jia Li, Y., Sheng Li, T. 2015. Brain Abscess Caused by Bacillus megaterium in an Adult Patient. Chinese Medical Journey Vol. 128, Issue 11.

Pringgenies, D. 2009. Biopropeksi Bakteri Simbion Dari Gastropoda Conus miles Terhadap Strain Bakteri MDR(Multi Drug Resistant). IImu Kelautan Vol. 14(1):42-49.

Pringgenies, D., Jurniati, M., Ridho, A. 2015. Aktivitas Antibakteri Ekstrak Nudibranch Polka-Dot (Jorunna funebris) (Gastropoda : Moluska) Terhadap Bakteri Multidrug Resistant (MDR). IlmuKelautan Vol. 20(4):195-206.

Proksch, P., Edrada. A. R., Ebel, R. 2002. Drugs From The Seas - Current Status and Microbioligical Implications. Applied Microbiology and Biotechnology 59 : 125-134.

Rinehart, K. L., Holt, T. G., Fregeau, N. L., Stroh, J. G., Keifer, P. A., Sun, F., Li, L. H., Martin, D. G. 1990. Ecteinascidins 729, 743, 745, 759B, and 770 : Potent Antitumor Agents From the Caribbean Tunicate, Ecteinascidia turbinate. J. Org. Chem. 55:4512.

Runtuwene, R. K., Wewengkang, D. S., Citraningtyas, G. 2017. Aktivitas Antibakteri Ekstrak Bintang Laut Linckia laevigata yang Diperoleh dari Teluk Manado. Jurnal IImiah Farmasi - UNSRAT Vol. 6, No. 4.

Warouw, V .dan Losung, F. 2015. Potensi Substans Anti-UV Dari Serangga Laut Family Gerridae Di Tasik Ria Mokupa Manado, Sulawesi Utara. Jurnal LPPM Bidang Sains dan Teknologi, 2(2): hal. 95-102.

WHO. 2014. Antmicrobial resistance: global report on survaillance 2014. World Health Organization. Hal. 257.

Yan, H. Y. 2004. Harvesting Drugs from the Seas and How Taiwan Could Contribute to This Effort. Changhua J Med Vol. 9, No. 1. 